\title{
Economic realities lead to reductions at JPL
}

\begin{abstract}
Washington. Responding to shrinking business and overcrowding, the US Jet Propulsion Laboratory (JPL) in Pasadena, California, plans to cut its work force of 7,500 by about 1,000 over the next five years. Although most of the cuts will come from attrition and slower hiring, some redundancies are also likely; in addition, the plan calls for closing down rented offices and consolidating workers on the main campus.

The size of the cuts signals a changing role for the laboratory, which has managed nearly every US solar system exploration mission for the past 30 years. Although JPL managers as well as outsiders see the move as an appropriate response to the recession in the US aerospace industry, centred on southern California, it also marks an end to an era when JPL could depend on a steady stream of billion-dollar projects such as Viking, Voyager and Galileo to keep its engineers and scientists busy. The National Aeronautics and Space Administration (NASA), which contracts JPL's services through the California Institute of Technology, has made it clear that there will be smaller, cheaper planetary missions in future, and these projects will require fewer staff.
\end{abstract}

The shift to smaller missions, no easy task in itself, will also eliminate JPL's monopoly on planetary exploration. NASA has hired the Applied Physics Laboratory of Johns Hopkins University near Baltimore, Maryland for one of its first low-budget 'Discovery' missions - the Near-Earth Asteroid Rendezvous (NEAR) - - marking the first time a planetary project has been handled by a non-NASA centre. In fact, one of the goals of the Discovery programme is to involve more industry and university teams as principal contractors. NASA is under political pressure to help the beleaguered US aerospace industry, and one way of doing that is to transfer to industry contractors the work traditionally done at centres such as JPL.
With new competition for a dwindling number of planetary missions, the laboratory must either scale back or find new business. In the 1980s, the rapid buildup in the US military and the large and complex planetary missions led to more staff. But those opportunities are gone, and JPL may well begin to look as it did in the $1960 \mathrm{~s}$, when smaller spacecraft such as Mariner and Pioneer were being launched and its work force was smaller.

If that occurs, the reduction of 14 per cent in its work force may help JPL to survive lean times; other NASA centres, full of civil servants and protected by home-state politicians, are more resistant to pruning. By comparison, President Bill Clinton's plan to shrink the federal payroll by a quarter requires NASA to cut only 1,000 of its 25,000 federal workers by 1997 - a reduction of 4 per cent.

Tony Reichhardt

\section{Indian budget favours space, atomic energy}

New Delhi. Indian scientists say that an increase of US\$100 million in a research budget of $\$ 1.3$ billion for 1993-94 announced last week by the government falls far short of meeting the needs of science. Most of the increase is earmarked for atomic energy and space, and the budget of the University Grants Commission has been reduced. In addition, science administrators have complained about the increased competition to national laboratories from foreign technologies now allowed into the country, and the lack of money for developing technologies to strengthen Indian industry. The government has proposed an income tax exemption on contributions from industry to national laboratories to help those institutions bridge the funding gap.

K.S. Jayaraman

\section{London meeting on British science}

On Friday 19 March, there will be a meeting at the Royal Society, 6 Carlton House Terrace, London SW1, to discuss proposals for the forthcoming White Paper on the organization of British science. The speakers will be Sir Eric Ash (Rector, Imperial College London), Professor Michael Brady (University of Oxford), Dr Dai Rees (Secretary, Medical Research Council) and Sir Mark Richmond (Chairman, Science and Engineering Research Council); the meeting will start at 9.30 a.m. and end at 4.00 p.m.

Admission to the meeting will be by ticket, free of charge, obtainable from Mary Sheehan, Nature, 4 Little Essex Street, London WC2R 3LF. Coffee and tea will be provided.

There will also be a sandwich lunch for those who want it, at a cost of $£ \mathbf{5}$ : please send a cheque made out to Nature with your ticket application.

\section{US purchase of British computer raises controversy}

Washington. A recent decision by a US government weapons laboratory to buy a massively parallel computer from a British-owned company has touched off protests from US supercomputer manufacturers and raised questions about trade policy in the competitive international computer market. The Lawrence Livermore (California) National Laboratory, which is government-funded but privately operated, is negotiating a contract reportedly worth $\$ 15$ million with Meiko Scientific Corporation of Waltham, Massachusetts, a wholly owned subsidiary of Meiko World Ltd of Bristol, for a computer to be used in weapons-related research.

The planned purchase has generated controversy on two counts. Critics, including US companies who bid unsuccessfully, are upset that the government would buy from a non-US company - even though there is no law forbidding it. But David Schwoegler, a spokesman for Livermore, says that the machine in question was designed entirely in the United States and that 85 per cent of it was built there. Meiko has sold computer equipment to the US government in the past.

Critics also regard the 1991 sale by Meiko of advanced computer equipment to an Israeli university as a breach of a USJapanese agreement restricting the sale of computers that might be used for weapons design. In this case, however, the sale was made by the British company, which was not subject to any such restrictions.

Jonathan Streeter of the US Department of Commerce admits that it is difficult to define a 'US company'. In the case of the sale to Israel, Meiko was acting as a British company while with Livermore it is asking to be regarded as a US company.

Danny Hillis, chief scientist for Thinking Machines Corporation of Cambridge, Massachusetts, one of the losing bidders, says that his company is upset not on the basis of trade policy but rather because Meiko is selling Livermore a computer that has not as yet been developed, as the rules require. "As near as we can tell, the machine [that the lab is buying] doesn't exist", he says.

Schwoegler denies this accusation, saying that the machine is "off-the-shelf". A spokesman for Meiko refused to say whether the computer being sold to Livermore is in production or whether there have been previous sales. Hillis said that his company would reserve judgement on whether to file a formal protest until the terms of the contract are made public.

Tony Reichhardt 